\title{
The Problem of the Implementation of Criminal Certification on Corporate Social Responsibility (CSR) on Business Conduct in Mining in Indonesia
}

\author{
Bambang Eryanto Hermawan \\ Doctoral Program of Law Science \\ Brawijaya University \\ Malang, Indonesia \\ b_e_hermawan@yahoo.co.id
}

\begin{abstract}
The nature and certainty of law in determining the existence of a government's initiative towards Corporate Social Responsibility (CSR) is to ensure in that action the existence of a social principle and environmental protection that must be regulated legally. Of course, there is an implication which means a legal certainty for mining business actors to help socially to the community in the area around the mine and preserve the environment, not merely the arbitrary exploitation of mines for the benefit of the person or his company, where in Law No. 4 of 2009 there is no set outline, if CSR is not implemented, then this need to tightly supervise the government thoroughly to the environment and social assistance to communities around the mining area. In order to apply criminal sanctions to mining business actors that do not provide social assistance and environmental concerns to surrounding mining areas, criminal sanctions have not been regulated and applied to mining business actors who have been granted mining license by the government in Indonesia. Sometimes the CSR that has been made the agreement alone is still much violated by business actors without any criminal sanctions.
\end{abstract}

Keywords- No Regulation of Criminal Sanctions For CSR

\section{INTRODUCTION}

Corporate Social Responsibility (CSR) is born out of the public or society's insistence on the company's social behavior in the mining business around the mining area that usually neglects its social responsibility to the environment and the people around the mining area.

Today there are many definitions that explain the meaning of CSR, which also continues to change over time. CSR, among others, is defined as a sustainable commitment of mining businesses, to behave ethically and contribute socially to economic development, while improving the quality of life of employees and their families, as well as local communities and the broader society at large.

Corporate social responsibility is ethically responsible social behavior towards society beyond economic responsibility. In this case about corporate social responsibility, the intent is the activities undertaken by the company for a social purpose by not taking into account economic profit or loss. It can happen in two ways: positive and negative ways, as follows:
1. Positively, a company may engage in activities that do not bring economic benefits and are solely for the sake of the welfare of the community or one of its groups. For example, organizing skills training for unemployed. Such activities only spend money and get nothing back. The goal is purely social and has absolutely no economic purpose or profit from CSR activities;

2. Negatively, the company can refrain from conducting certain activities, which are actually profitable in terms of business but will harm society or some people. These activities can bring economic benefits but companies have reason not to do so because CSR activities must be social in the area around the mine.

If the above description can distinguish the social responsibility in the sense of positive and negative meaning, directly become clear consequences in the framework of ethics and social behavior of companies in doing activities for CSR.

Now, as the complexity of ownership of a business, the concept of CSR becomes widespread, one of which is the goodwill and commitment of the company to contribute to improving the quality of life of the community, sustainability of community development and local economy so as to contribute also to the sustainability of the company. These activities are conducted by building a harmonious relationship between the company and its employees, their families, local communities (communities), and the environment at large.

CSR is not just an effort to obtain social consent from the public to secure the company's operations or to reduce environmental losses from its business activities, but further CSR is an effort to improve the quality of life of stakeholders (according to their priorities). Thus, caring for social consequences, addressing environmental losses as a result of business activities, social consent from the community becomes a small part of the effort to improve the quality of life. Stakeholders formulated above (employees, buyers, owners, suppliers, and local communities, non-profit organizations, activists, government and the media), basically have the same goal of prosperity. The Company not only has economic and legal obligations (meaning to shareholders or shareholders) but also obligations to other stakeholders whose scope exceeds the above obligations. 
In the case of CSR, the need for corporate social responsibility, in the midst of a social and public environment, is now increasingly critical of the various business practices undertaken by the company. As an example of mining in Indonesia, Freeport mining companies in Papua are often criticized for environmental destruction.

Regarding the company building the local village, it is related to Social and Environmental Responsibility (CSR) or Corporate Social Responsibility (CSR). TJSL / CSR is not only about activities undertaken by companies in which the company participates in the economic development of local communities, but also related to the company's obligations in preserving the environment which has been regulated in various laws and regulations, as follows:

1. Law no. 22 of 2001 on Oil and Natural Gas;

2. Law no. 25 Year 2007 regarding Investment;

3. Law no. 40 Year 2007 regarding Limited Liability Company;

4. Law no. 32 of 2009 on the Protection and Management of the Environment;

5. Government Regulation no. 47 Year 2012 on Corporate Social and Environmental Responsibility of Limited Liability Company;

6. Regulation of the Minister of State-Owned Enterprises Nos. PER-05 / MBU / 2007 Year About the Partnership Program of State-Owned Enterprises with Small Business and Community Development Program as lastly amended by Regulation of the Minister of State-Owned Enterprise. PER-08 / MBU / 2013 Year 2013 On the Fourth Amendment to The Regulation of The Minister of State Owned Enterprises. PER-05 / MBU / 2007 About Partnership Program State-Owned Enterprises with Small Business and Community Development Program.

Where in Law Number 4 Year 2009 regarding Mineral and Coal Mining (UU Minerba), replacing Law Number 11 Year 1967 regarding Provisions on Mining Basic Principles (Law No.11 Year 1967) is not regulated in relation to Social Responsibility and Environment (TJSL) or Corporate Social Responsibility (CSR), in which there is a legal vacuum in Law Number 4 Year 2009, so the company is not legally obligated because CSR is voluntary based on moral values rather than legal order (coercion).).

\section{DISCUSSION OF CSR PROBLEMS}

As a mining venture, the objective of a mining company is to maximize profits through mining in the most effective and efficient manner possible. Mining companies generally operate in remote areas with minimal facilities. Meanwhile, in operation, mining companies are supported by mining experts and other non-mining personnel who live together in a community that is completely different from the surrounding community, both in terms of physical and nonphysicalfacilities.

The special environment is complete all the facilities often lead to jealousy from the surrounding community who live minimal facilities and low levels of social life of the economy. Not to mention the impact of pollution from labor activities and mining activities on the environment and surrounding communities. Jealousy is what often leads to conflict between the management of companies and communities around the mine. On the other hand, the company feels that it has fulfilled all its obligations as a company to the Government by paying taxes or royalties.

It is ironic to see the condition of the community coupled with the location of a large mining business. Many of them live in a very mediocre conditions despite the place there is a very successful company to gain profit. Communities around Freeport, Timika, West Papua for example, they must stealthily sneak up life while avoiding custody of armed officers in the Freeport tailings stream.

In addition to the above-mentioned problems, in the early stages, mining concessions have also been faced with a negotiation process with landowners where there is sufficient deposit of mining materials to be profitably exploited. This stage is also a critical stage because it can affect the future of the relationship between society and mining companies.

In order to eliminate any problems that may arise as mentioned above, it should be right from the beginning that mining companies can show their corporate social responsibility (CSR) through community development (CD) or Community Empowerment program. It is very important to convince the public that the presence of mining companies that will dominate the natural resources in the region will compensate them in the form of programs that will improve the socioeconomic welfare of the population.

Currently, CSR has become a business issue that continues to strengthen. This issue is often disputed with ethical values approaches, and puts increasing pressure on businesses to play a role in social is sues, which will continue to grow. CSR issues themselves are also often raised by businesses, when national governments in various countries have failed to offer solutions to various social problems.

But the effort of implementing CSR itself is not without obstacles. Of economists thems elves also emerged a reaction to criticize the concept of CSR, with the argument that the main purpose of the company is essentially to maximize returns (returns) for shareholders, at the expense of other things. There are also people who think, the only reason why companies want to do projects that are social is because there is a commercial advantage behind it. That is, raising the reputation of the company in the eyes of the public or government. Therefore, business people must show with clear evidence that their commitment to implement CSR is not a joke.

The benefits of CSR itself to business people also vary, depending on the nature of the company concerned, and it is difficult to measure quantitatively. Nevertheless, there is a large a mount of literature that indicates a correlation between social / environmental performance with the financial performance of firms. CSR will ultimately benefit the company. But, of course, companies are not expected to get short-term financial rewards, when they implement CSR strategies. Because that's not the goal.

In order for more mining companies willing to behave nobly towards the environment and surrounding communities, the government can provide supporting facilities, one of them in the form of tax incentives. The form can be tax exception (tax exemption) or tax reduction (tax deduction). Tax incentives will encourage companies to be more aggressive in developing CSR programs. 


\section{A. Outlook and Corporate Thoughts on CSR}

Each company has a different perspective and opinion on CSR, and this way of thinking and thought that can be used as an indicator of the company's earnestness in implementing CSR or just make the image in the community. There are at least three categories of corporate paradigms in implementing CSR programs, including:

1. First, just manners, manners and compulsion, meaning that CSR is practiced more because of external factors, both because it controls social aspects (social driven) and environmental aspects (environmental driven). This means that the fulfillment of social responsibility is more due to the compulsion due to demands than volunteerism. Next is to control the reputation (reputation driven), namely the motivation of CSR implementation to boost the company's image. Many corporations are deliberately trying to boost the image by exploiting natural disaster events such as giving aid money, basic foods, medical and so forth, which then the company is competing to inform its contribution through the mass media. The goal is to lift the reputation.

On the one hand, it is indeed encouraging, especially in relation to the real needs of disaster relief and a sense of human solidarity. This phenomenon raises a question mark mainly related to the commitment of humanitarian solidarity itself. That is, the intention to donate is still filled with the will to seize the opportunity to do positive publications, for example to maintain the good name of the company or boost the corporate image.

2. Secondly, in an effort to fulfill the obligation (compliance) and the implementation of existing regulations and or laws. CSR is implemented because there are regulations, laws and rules that force it. For example, because there is control in the market aspect (market driven). Awareness of the importance of implementing CSR is becoming a trend in line with the widespread global public awareness of products that are environmentally friendly and produced with due regard to social rules.

In addition, there are other aspects that can force companies to practice CSR is the rewards (rewards) provided by all institutions or institutions. For example, CSR Award, both regional and global, Community Power Guides (Padma) held by the Ministry of Social Affairs (MOSA), and the Program of the Company Performance Device (Proper) run by the Ministry of Environment.

3. Third, not just obligations (compliance), but more than sekdar obligations (beyond compliance) or (compliance plus). Implemented because there is a genuine drive from inside (internal driven). The company has realized that its responsibility is not just economic activity to create profit for the sake of business continuity, but also social and environmental responsibility. His rationale, relying solely on financial health will not guarantee the company can grow sustainably.

The Company believes that the CSR program is an investment for sustainable growth and sustainability. That is, CSR is no longer seen as a cost center (cost center) but the center of profit (profit center) in the future. The logic is that if CSR is ignored, then the incident occurs, then the cost to limit the risk is much greater than the value to be saved from the CSR budget allocation itself. Not to mention the nonfinancial risks that adversely affect the corporate image and public confidence in the company.

Therefore, CSR is no longer just a sticky activity that if forced to be sacrificed in order to achieve efficiency, but CSR is the life of the corporation. CSR has entered the heart of corporate strategy. CSR is addressed strategically by initiating CSR with corporate strategy. The trick is that CSR initiatives are conceptualized to improve the competitive context of the corporation in the form of quality business where the corporation operates.

\section{B. Community Empowerment in the Field of Mining}

Community Development (CD) or Community Empowerment is one of the activities that are part of the CSR program in the mining sector. CD consists of Community Relation which is the development of understanding through communication and information to stakeholders, which mostly done to local community and Local Government, then Community Service is program of relief aid related to public service or public interest including aid for natural dis aster, aid public infrastructure including places of worship and health promotion for local communities.

Next is community empowering, an effort to empower people to have good access to support their independence, for example scholarship programs, capacity-building of local community-based enterprises and assistance for the development or strengthening of self-help groups.

The latter is a conservation or natural conservation program that is doing reforestation by empowering local communities so as to increase the income of farmers or farmers. The whole program of Community Development or Community Empowerment activities should be sustainable with clear criteria of success. There are six important dimensions of community development, namely:

1. Social development;

2. Economic development;

3. Political development;

4. Cultural development;

5. Environmental development; and

6. Personal / religious development.

The objectives of community development in mining and oil and gas industry according to Budimanta are as follows:

1. Support efforts undertaken by local governments (LGs ), especially at the village and community levels to improve socio-economic-cultural conditions better around the area of company activity.

2. Provide work and strive opportunities for the community.

3. Assisting local governments in the context of poverty alleviation and regional economic development. 
4. Strategy to prepare the community life around the mine's circle when the industry has ended its operation (life after mining or oil)

According to Budimanta stated that the participants of the community development program should be focused on the community around the mine and prioritized to the community related to the direct impact of the company's activities. Communities directly related to the activities of the enterprise are basically a combination of local communities that may consist of indigenous peoples and also settlers residing in the relevant location.

According to Primahendra, based on community role aspect, community development practice can be grouped into three forms, they are:

"Development for community, where people become the object of development because various initiatives, planning, and implementation of development activities carried out by outside actors".

Development with community, where a collaboration pattern exists between the outside actors and the local community so that the decisions taken are a shared decision and the resources used come from both sides. Development of community, where a good development process of initiative, planning, and implementation is carried out by the community itself..

\section{Implementation Phases of CSR}

There are stages to be done when the company will do the CSR program, according to Wibisono, there are at least four stages, including:

\section{1) Planning Phase}

Planning there are three main steps, namely awareness building, CSR Assessment, and CSR manual building. Awareness building is the first step to build awareness about the importance of CSR and management commitment. This effort can be done, among others, through seminars, workshops, group discussions, and others.

CSR Assessment is an effort to map the company's condition and identify the aspects that need to get priority attention and appropriate steps to build a company structure that is conducive to the effective implementation of CSR.

The next next is to create a manual CSR. The results of the assessment are the basis for developing manuals or guidelines for the implementation of CSR. Efforts to be made include through benchmarking, digging from referrals or using experts.

Manual is the core of planning, because it becomes a guide or guidance of CSR implementation for company component. Preparation of CSR manual is made as a reference, guidance and guidance in the management of social activities undertaken by the company. These guidelines are expected to provide clarity and uniformity of mindset and pattern of action of all ele ments of the company to achieve the implementation of an integrated program, effective and efficient.

\section{2) Implementation Phase}

Planning as good as anything will be meaningless and will not have any impact if it is not implemented properly. As a result, the overall objectives of CSR will not be achieved, and the community will not feel the optimal benefits. Though the budget has been disbursed can't be considered small. Therefore, it is necessary to formulate a strategy to implement the plan that has been designed.

In starting the implementation, basically there are three aspects that must be prepared, namely; who will run, what to do, and how to do the implemenation and what tools are needed. In the case of popular management, that aspect is translated into:

1. Organizers, or resources required;

2. Staffing to place people according to the type of task or job they have to do;

3. Direction (directing) as sociated with how to takeaction;

4. Supervision or controlover implementation;

5. Implementation of work in accordance with the plan;

6. Evaluating to know the level of goal achievement.

This implementation stage is composed of three main steps, namely socialization, implementation and internalization. Socialization is needed to introduce to company components on various aspects related to the implementation of CSR especially regarding guidelines for CSR implementation. To be effective, this effort needs to be done with a team or special division established to manage the CSR program, directly under the supervision of one of the directors or CEOs. The main objective of socialization is that the CSR program to be implemented has full support from all components of the company, so that in its journey there are no serious obstacles that can be experienced by the organizer unit.

Implementation of activities carried out basically must be in line with existing CSR guidelines, based on the roadmap that has been prepared. While internalization is the long-term stage. Internalization includes efforts to introduce CSR in all aspects of a company's business, for example through performance management systems, procurement procedures, production processes, marketing and other business processes. With this effort can be stated that the implementation of CSR is not just cosmetics but has become a corporate strategy, no longer as an effort to compliance but has been beyond compliance.

\section{3) Evaluation Phase}

After the program is implemented the next step is program evaluation. The evaluation stage is the stage that needs to be done consistently over time to measure the effectiveness of the implementation of CSR. Sometimes there is an impression, a new evaluation is done if a program fails. Meanwhile, if the program is successful, it is not evaluated. Though the evaluation should still be done, either when the activity is successful or fail. Even failures or new successes can be known after the program is evaluated.

Evaluation is also not an action to find fault. Evaluation is done as a means for decision making. For example, the decision to stop, continue, improve or develop certain aspects of the program that has been implemented

\section{4) Reporting Phase}

Reporting is done in order to build an information system both for the purpose of the process of returning the decision and the need for disclosure of material and relevant information about the company. So, in addition to 
functioning for the purposes of shareholders also to stakeholders who require.

\section{Benefits of CSR}

Companies can also benefit from CSR activities.

1. Reduce the risk of negative allegations addressed to the company;

2. CSR serves as a protective shield in order to help companies minimize impact;

3. Bad resulting from a crisis;

4. CSR can strengthen the relationship between the company and its stakeholders;

5. Community Development (CD) as a Tool for Running Corporate Social Responsibility.

One form of implementation of the CSR program is community development (CD), the explanation can be seen above. The essence of community development is a series of activities to increase the independence and ability of the community (especially the poor) to be willing and able to access various resources, capital, technology, and markets with a mentoring approach, to improve their welfare (Lubis, et al,)

According to Ife, community development aims to rebuild society by placing it as an interconnected human being and need each other instead of interdependence to a larger one that is more inhumane, has welfare, broader economy, bureaucracy, and the ability to choose, etc.

\section{E. The Related Laws of CSR No Regulating Rules for Criminal Sanctions}

In this case, you did not mention what type of company it is. Therefore, we will explain about TJSL in various laws and regulations, as follows:

1) Law No. 40 Year 2007 regarding Limited Liability Company ("UUPT") and Government Regulation No. 47 Year 2012 on Corporate Social and Environmental Responsibility ("PP 47/2012")

Regarding the TJSL, stipulated in Article 74 UUPT and its explanation. This arrangement applies to the company. Based on Article 1 number 1 of Company Law, Limited Liability Company is a legal entity which is a capital alliance, established under the agreement, conducting business activities with the authorized capital wholly divided into shares and fulfilling the requirements stipulated in this Law and its implementing regulations.

According to Article 1 Sub-Article 3 of the Company Law, Social and Environmental Responsibility is the company's commitment to participate in sustainable economic development in order to improve the quality of life and the environment that is beneficial both for the company itself, the local community, and the community at large.

Article 74 of the Company Law basically stipulates the following matters:

1. This TJSL is required for a company that carries out its business activities in the field and / or related to natural resources. So, what is meant by "a company that carries out its business activities in the field of natural resources" is a company whose business activities are managing and utilizing natural resources. Whereas "a company that carries out its business activities related to natural resources" is a company that does not manage and does not utilize natural resources, but its business activities have an effect on the function of natural resource capability;

2. This TJSL is a corporate liability that is budgeted and calculated as the cost of the company whose implementation is carried out with due attention to decency and fairness;

3. Regarding sanctions, it is said that the company that does not perform the obligations of TJSL will be subject to sanctions in accordance with the provisions of the relevant legis lation.

In Article 4 of Regulation 47/2012, it is said that the TJSL is executed by the Board of Directors based on the company's annual work plan after obtaining approval from the Board of Commissioners or General Meeting of Shareholders ("GMS") in accordance with the articles of association of the company. The company's annual work plan contains the activities and budget plans required for the implementation of TJSL The implementation of the TJSL is contained in the company's annual report and accountable to the GMS (Article 6 PP 47/2012).

2) Law no. 25 Year 2007 regarding Investment ("Law 25/2007")

Article 15 letter b of Law 25/2007 stipulates that every investor is required to implement TJSL. The meaning of TJSL pursuant to the Elucidation of Article 15 Sub-Article b Law 25/2007 is the responsibility attached to each investment company to keep creating a harmonious, balanced, and appropriate relationship with the environment, values, norms and culture of the local community.

While the meaning of investors is individuals or business entities that make investments that may be domestic investors and foreign investors (Article 1 number 4 of Law 25/2007).

In addition, Article 16 of Law 25/2007 also provides that every investor is responsible for preserving the environment. This is also part of TJSL If the investor does not perform its obligations to imple ment TJSL, then under Article 34 of Law $25 / 2007$, investors may be subject to administrative sanctions in the form of:

1. written warning;

2. restrictions on business activities;

3. freezing of business activities and / or investment facilities; or

4. revocation of business activities and / or investment facilities.

In addition to being subject to administrative sanctions, investors may also be subject to other sanctions in accordance with the provisions of legislation (Article 34 paragraph (3) of Law 25/2007).

3) Law no. 32 of 2009 on Protection and Environmental Management ("Law 32/2009")

Under Article 68 of Law 32/2009, every person conducting business and / or activity is obliged to:

1. Provide information related to the protection and management of the environment properly, accurately, openly and in a timely manner; 
2. Maintaining the sustainability of environmental functions; and

3. Comply with the provisions on environmental quality standards and / or standard criteria for environmental damage.

4) Regulation of the State Minister of State-Owned Enterprises no. PER-05 / MBU / 2007 Year 2007 concerning Partnership Program State-Owned Enterprises with Small Business and Community Development Program as lastly amended by Regulation of the Minister of StateOwned Enterprise. PER-08/MBU/2013 Year 2013 On The Fourth Amendment To The Regulation Of The Minister Of State Owned Enterprises. PER-05 / MBU / 2007 Concerning Partnership Program of State-Owned Enterprises with Small Business and Community Development Program ("BUMN 5/2007")

The regulation stipulates the obligations of the Company ("Persero"), Public Corporation ("Perum"), and Public Company ("Persero Terbuka"). Based on Article 2 of BUMN 5/2007, \{Persero and Perum) are required to implement BUMN Partnership Program with Small Business and Community Development Program. While the Open Persero can implement BUMN Partnership Program with Small Business and Community Development Program based on the Minister of SOE 5/2007 stipulated based on the resolutions of the GMS.

BUMN Partnership Program with Small Business is a program to improve the ability of small-scale enterprises to become strong and independent through the utilization of state-owned funds (Article 1 number 6 BUMN 5/2007). While the Community Development Program is a program of community social empowerment by state-owned enterprises through the utilization of state-owned funds (Article 1 point 7 BUMN 5/2007).

5) Law no. 22 of 2001 on Oil and Natural Gas ("Law 22/2001")

Upstream business activities carried out by a Business Entity or Permanent Establishment under a Cooperation Contract with the Implementing Body shall contain the main provisions of which one of the provisions concerning the development of the surrounding community and the guarantee of the rights of indigenous peoples (Article 11 paragraph (3) letter p Law 22/2001).

In addition, Article 40 paragraph (5) of Law 22/2001 also states that Business Entities or Permanent Establishments conducting Oil and Gas business activities (upstream business activities and downstream business activities) are responsible for developing the environment and local communities.

6) Law No. 4 of 2009 on Mineral and Coal Mining (Minerba Law)

Where in Law Number 4 Year 2009 regarding Mineral and Coal Mining (UU Minerba), replacing Law Number 11 Year 1967 regarding Provisions on Mining Basic Principles (Law No.11 Year 1967) is not regulated in relation to Social Responsibility and Environment (TJSL) or Corporate Social Responsibility (CSR), in which there is a legal vacuum in Law Number 4 Year 2009, so that the company is not legally obligated because CSR is voluntary based on moral values rather than legal order (coercion).
TJSL as a concept of responsibility in the meaning of Liability or legal liability, which is the legal responsibility arising from the failure to meet the standards established by law. Related to the provisions of sanctions TJSL set in (UUPT) and (PP TJSL) is still considered has not been able to meet legal certainty, because the imposition of sanctions if not perform obligations (TJSL) has been mandated to other laws and regulations, without providing certainty of legislation intended as described above.

\section{F. Regulation of Criminal Sanctions for Limited Liability Companies Conducting Violations of Non- Implementation of Social and Environmental Responsibility Related to Business Activities in Natural Resources}

In the understanding of criminal law, the company as a legal entity is better known as "corporation". The important role in economic development is considered to be an employer, producer, price determinant, and other roles concerning the welfare of society. In order to determine an act of criminal liability, it must be known beforehand that it is unlawful or unspecified according to the laws and regulations of the "legality principle" and based on general principles of non-written law.

But the requirement for criminal detention is not sufficient only with that person to have violated the law, but must also qualify that the person doing the deed has a (scuhld) error. In accordance with the principle of "Geen straf zonder schuld". It is very difficult to define criminal liability for corporations that must contain an element of mistake that is equivalent to human error naturally. In accordance with Article 10 of the Criminal Code consisting of principal punishments, capital punishment, imprisonment, confinement and penalties, as well as additional crime consisting of the revocation of certain rights, the deprivation of certain goods, and the announcement of the judge's decision.

In civil law the emergence of accountability is due to two abuses. namely, broken promise (Wanprestasi) based on the contractual agreement, as set forth in "Article 1239 Civil Code" and Unlawful Acts, in accordance with the provisions of Article 1356 of the Civil Code. Accountability of both actions may occur if it has caused harm to the other party. Default occurs because of a contractual relationship between the contracting parties, which is known under the principle of Pacta sun servanda "all legally arranged agreements act as laws for those who make them"

Some of the sanctions that are known in the concept of administrative law include Government Coercion (Bestuurdwang), Withdrawal of Coercive or Fines, Withdrawal of decisions that may be revocation of permits. For co mpanies related to natural resources that have done the action of pollution and damage of natural resources and impact on the conservation function of natural resources, it is deemed to have violated the permit that has been set so that it can be subject to administrative sanction. So the determination of the appropriate form of sanction applied to companies related to natural resources is by imposing administrative sanctions. 


\section{CONCLUSIONS}

The image of a bad mining company, often raised in the mass media, clearly does not support the smooth operation of the company and is counterproductive to efforts to increase productivity and profit. It is now increasingly acknowledged that the company as a businessman, will not be able to continue to grow if you close your eyes or do not want to know the situation and conditions of the social environment in which he lived.

In this connection, the implementation of corporate social responsibility (CSR) through community development (CD) program is seen not only as a responsibility, but also an obligation. CSR is a business role and should be part of business policy. Thus, business not only takes care of profit problems, but also must contain social awareness of the surrounding environment. In line with the current dynamics, it is concluded that there are six main trends that increasingly emphasize the importance of CSR, namely:

1. Increasing the gap between rich and poor;

2. The position of the increasingly distant state of the people;

3. The more the meaning of sustainability;

4. Increasingly critical spotlight and resistance from the public;

5. Trends toward transparency;

6. Hopes for a better and more humane life in the new millennium.

The description of the above problems could threaten the sustainability of the CSR program. Sustainability is an important element in the realization of CSR programs, because the aspect of sustainability is a concept that outsmart community development programs or community empowerment. In the context of sustainable development, there are preconditions, including good governance, healthy civil society, environment that is not damaged by economic activities. In addition, the atmosphere of peace and justice is also a factor of sustainability of a program.

Frameworks and mechanisms of program management that are not based on the interests of the community cause the program created also does not represent the needs of the community. Programs are elitist and aimed at corporate and interest groups. This gives rise to jealousy and public reluctance to participate. Moreover, the CSR program raises rejection of the program.

The main problem causing this is that CSR programs are not community-based. The motive of the company to realize the program that is not based on the desire to serve the community and the non-transparent management resulted in the realization of the program is exclusive. This does not stimulate the emergence of participation.

It is necessary to regulate criminal sanctions against negligence or violation in the implementation of CSR in the interest of civilization to replace Law No. 4 of 2009 on Mineral and Coal Mining in order to be regulated in relation to Social and Environmental Responsibility (TJSL) or Corporate Social Responsibility (CSR), in which there is a legal vacuum and the application of criminal sanctions so that the mining entrepreneurs do not have the right to explore the mine, so the company has a legal obligation because CSR is compulsory and coercive based on ethical, moral, environmental sustainability and legal protection to the civilization of society for the sake of harmony and preservation of air, soil, water, and nature in the ecosystem of life in the universe.

\section{REFERENCES}

[1] Abiodun, B.Y. (2012). The Impact of Corporate Social Responsibility on Firm's Profitability in Nigeria. European Journal of Economics, Finance and Administrative Sciences, Issue 45.

[2] Chauhan, Swati. (2014). A Relational Study of Firm's Characterist ics and CSR Expenditure. Procedia Economics and Finance 11.

[3] Choi, J.S., Kwak, Y.M., and Choe, C. (2010). Corporate Social Responsibility and Corporate Financial Performance: Evidence from Korea. Australian Journal of Management, 35, 291-311.

[4] James, Ife (2006). Community Development: Community Based Alternatifes in on age globalization. Australia, Pearson.

[5] Leimona, Beria \& Fauzi, Aunul (2008). CSR and Environmental Preservation Managing Impact: Positive and negative. Jakarta, IBL.

[6] Mcwilliam, A., and Siegel, D. (2000). Corporate Social Responsibility and Financial Performance: Correlation or Misspecification? Management Journal, Vol. 21, No. 5, pp. 603-609.

[7] Mulyadi (2003): Management of Corporate Social Responsibility Program: Approach, Alignment and Sustainability. Center for Populaton Studies, UGM.

[8] Mulyadi, M.S., Anwar, Y. (2012). Impact of Corporate Social Responsibility Toward Firm Value and Profitability. The Business Review, Cambridge, Vol.2, No.9.

[9] Rudito, Bambang \& Budimanta, Arif (2003). Methods and Techniques of Community Development Management. Jakarta: ICSD.

[10] Rudito, Bambang, et al. (2007). Business Ethics and Corporate Social Responsibility in Indonesia. Bandung: Engineering Science. Toutsoura, M. (2004). Corporate Social Responsibility and Financial Performance. University of California, Berkeley.

[11] Rudito, Bambang \& Budimanta, Arif \& Prasetijo, Adi (2004). Corporate Social Responsibility: An Answer to Indonesia's Current Development Capital. Jakarta, ICSD.

[12] Solihin, Ismail, (2009). Corporate Social Responsibility; From Charity to Sustainability. Jakarta: Salemba Four.

[13] Suharto, Edi (2005). Building People, Empowering People. Bandung Refika Aditama.

\section{RELATED LAWS AND REGULATIONS IN INDO NESIA}

[1] Law no. 22 of 2001 on Oil and Natural Gas;

[2] Law no. 25 Year 2007 regarding Investment;

[3] Law no. 40 Year 2007 regarding Limited Liability Company;

[4] Law no. 32 of 2009 on the Protection and Management of the Environment;

[5] Government Regulation no. 47 Year 2012 on Corporate Social and Environmental Responsibility of Limited Liability Company;

[6] Regulation of the Minister of St ate-Owned Enterprises Nos. PER-05 / MBU / 2007 Year About the Partnership Program of State-Owned Enterprises with Small Business and Community Development Program as lastly amended by Regulation of the Minister of StateOwned Enterprise. PER-08 / MBU / 2013 Year 2013 On the Fourth Amendment to The Regulation of The Minister of State Owned Enterprises. PER-05 / MBU / 2007 About Partnership Program Stat eOwned Enterprises with Small Business and Community Development Program;

[7] Law Number 4 Year 2009 regarding Mineral and Coal Mining (UU Minerba)). 